\title{
Engineering geology and remote sensing in the USSR
}

\begin{abstract}
Remote sensing techniques are an integral part of engineering geology studies in the USSR. The use of these techniques improves the reliability and quality of engineering geology studies, as well as decreases both the time required to perform the studies and their costs.
\end{abstract}

Many types of remote sensing are employed at a variety of scales, and these include airborne photography, space imagery, satellite scanner imagery, thermal infrared surveys, and radar remote sensing. The widespread applications of remote sensing data encompass seismic risk and dam safety assessment, permafrost zone mapping, mountain hazard mapping, and the assessment of man's impact on the geological environment, among others. (Ed.)

\section{Introduction}

Remote sensing techniques that incorporate photographic. video. thermal infrared, radar, and multispectra! surveys are used widely in enginecring geology investigations in the USSR. In fact. these techniques are considered to be an integral part of the general complex of methods that are employed in geological investigations for engineering purposes. They are applicd to (1) mapping and zonation. (2) ranking of geological and engineering geology processes. (3) revision and renewal of engineering geology maps, and (4) the study of today's geological environment and the prediction and definition of changes as a result of the impacts of technology.

Reliable engineering geology interpretations of remote sensing data are provided by contrast-analog, landscape-indicative, and morphostructural image analyses. When interpreting images. we use various techniques including successive approximation: analysis and synthesis of decoded information: individual. consulting. and comparative interpretation: and typification and extrapolation. Also. we apply methods of image transformation and automation. The results of our engineering geology interpretations are presented in various graphic, numerical, and descriptive models. as well as in airborne and space images and photographic maps. The use of remote sensing improves the reliability and quality of engineering geology studies. The length of time that is required to perform the necessary studies is shortened, and the cost of these studies is minimized (Konarov and Sadov, 1984).

\section{Types of imagery}

A erosurveys in the optical (visible) ranges have been used in engineering geology since 1940, and the techniques are well developed.
Surveys are carried out at different scales from 1:5.000 to 1:50.000 in black and white or in colored multizonal and spectrozonal versions. The methods for analysis of enginecring geology also are well developed. Useful information is provided about potential intensive technological impacts in the vicinity of a site, as well as for the wider region, although the possibility of using landscape-indicative methods is decreased strongly in areas where natural landscapes already have been disturbed by man. Under these conditions, geomorphological and geobotanical aspects of analysis are of great importance. Special photogrammetric techniques are used for the characterization of the relief (Sadov and Revson. 1979). Generally. studies of airborne photography help us define counters and squares for the areas of development of different geomorphological processes. observe morphometric characteristics, determine the dynamics of observed processes, and detine some factors that control the development of the processes.

Space imagery studies have been used in engineering gcology since 1970. Remote sensing materials have been prepared that have different levels of generalization and are applied to engineering geology investigations. The combined interpretations of acrial and space imagery are used as well. We have methods for processing an image in order to extract a significant local structure or a geologic process from data for a larger area. Our engineering geology maps show many small or local geological processes. such as karst, erosion, subsidence, Iandslides, or rockfalls. Therefore. the ground resolution of space imagery is of great importance. Analyses of space images in the visible ranges are carried out in two versions, both in black and white and in colored multizonal versions. Black and white photographs often provide less information than colored photographs do, but this information has higher resolution. Therefore, black and white photographs are used when detailed images are necessary. Colored multizonal photographs that have resolutions between 10 to $50 \mathrm{~m}$ and 5 to $8 \mathrm{~m}$ are used for the compilation of specialized mediun-scale and small-scale maps.

Satellite scanner imagery is used for the identification, observation. monitoring, and assessment of hazardous processes.

Thermal infrared (airborne) surveys are carried out in 2 to 5 $\mathrm{m} / \mathrm{km}$ and 8 to $14 \mathrm{~m} / \mathrm{km}$ ranges in both profile and areal versions. These techniques are used to observe regions for special purposes such as changing water-table levels, surficial soil-moisture analysis, surface-water contamination. and spontaneous combustion of coal and peat material.

Radar remote sensing (in microwave ranges from $1 \mathrm{~mm}$ to 30 $\mathrm{cm}$ and in the radio wave range up to $50 \mathrm{~m}$ ) is conducted in both active and passive versions. It can be used to measure the thickness of superficial deposits. soil moisture, and deph to ground-water level (Komarov and others, 1988).

\section{Selected research topics}

\section{Seismic risk and dam safety assessment}

In the mountainous regions of central Asia, one of the most tectonically and seismically active areas of the USSR, a series of major 


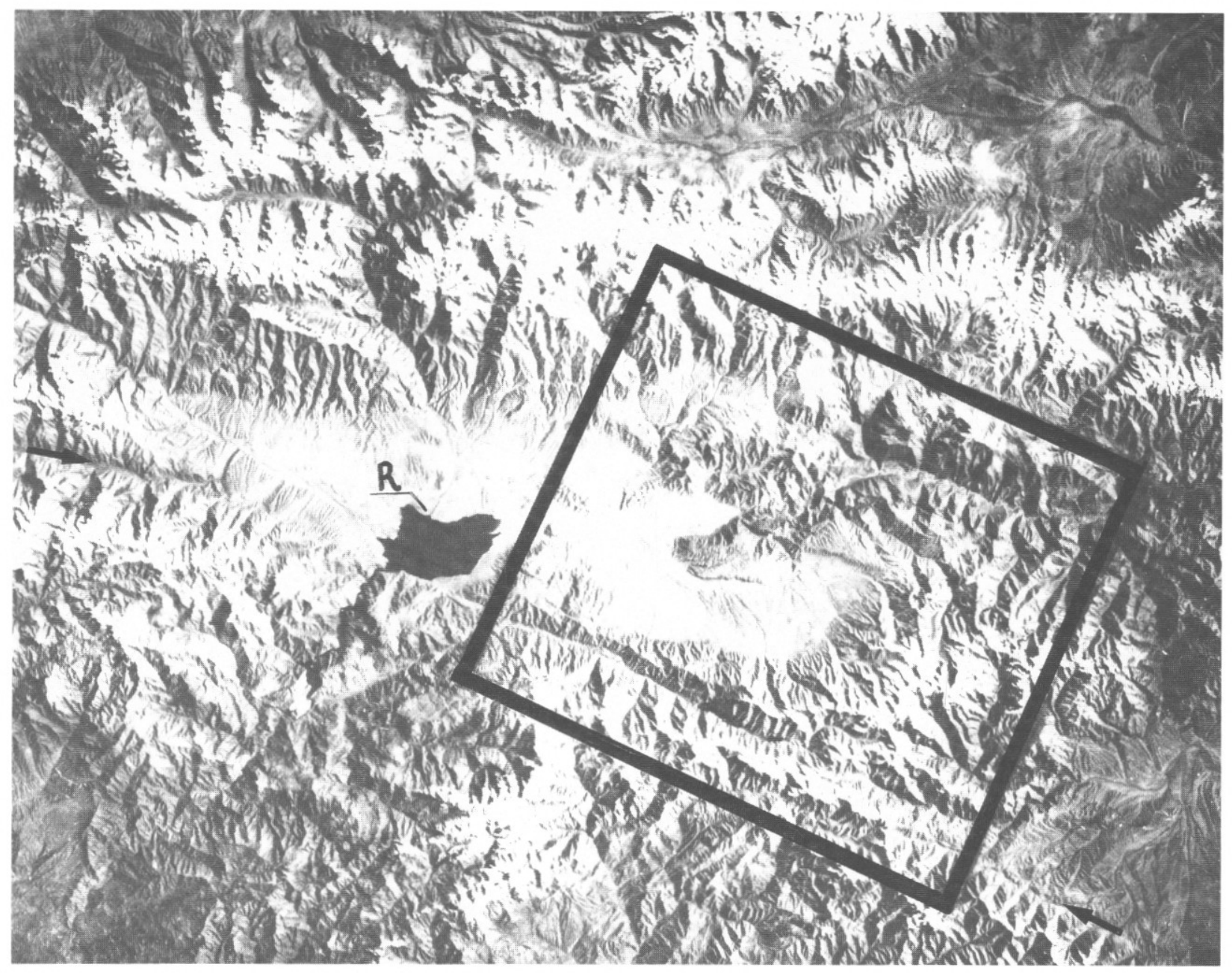

Figure 1.-Space photograph showing part of the Naryn River basin in the Kirgiz Republic. Arrows show the Talas-Fergana wrench fault, and $R$ is the Toktogul reservoir. The outlined area is figure 2.

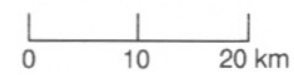

hydroelectric projects have been developed in order to provide irrigation water and electricity for the central Asian republics. These projects are at Toktogul, a 215-m-high concrete gravity dam; at Nurek, a 300-m-high earthfill dam; and at Rogun, a 335-m-high earthfill dam. The Hydroproject Association has performed analyses of potential seismic hazards for dam sites such as these by applying remote sensing methods.

Space images and airborne photographs are used for the geological investigations of dam sites and tunnel alignments. Images at different scales and resolutions, which range from satellite shots having scales of about 1:1,000,000 to detailed large-scale aerial photographs, are analyzed in order to identify, locate, and investigate faulting and slope processes. Methods have been developed that reveal special imagery features, such as landslides, rockfalls and rock avalanches, and broken watersheds and disrupted drainage patterns, for locating active faults. Data obtained from these space and aerial images are compared with geological maps and seismological data. These types of surficial dislocations can be interpreted (after specialized investigation) as residual deformations resulting from prehistoric, strong earthquakes.

The Kambarata project is in the Naryn River basin, which occupies the internal part of the eastern Tien Shan (mountain chain), in the Kirgiz Republic. The project, located to the east of the active Talas-Fergana wrench fault (fig. 1), is illustrated as an example. A design has been worked out for a 255-m-high rockfall dam that will be built by an oriented rock blast.

One of the difficult problems is the definition of seismic hazard at individual project sites. No strong earthquake has been recorded in this study region during the whole period of observation, and no historical data report such events. On the seismic zoning map of the USSR, the study region was included in seismic zones that have an intensity from seven to eight points on the MSK scale (similar to the Modified Mercalli scale).

Special analysis of stereoscopic satellite photographs, which have better than 10 -m resolution (fig. 2), shows a number of recent faults, landslides, and other dislocations in the eastern part of the Naryn basin (fig. 3). Areas were identified that needed more detailed ground investigations. The features were analyzed next on large-scale aerial photographs (fig. 4) and then were verified in the field. On the basis of this data, we delineated seismogenetic zones having high seismic potential $(M \max =7.0)$ and long recurrent intervals for the strongest events. The resulting seismic hazard of the project's dam sites within the study region was determined and received a nine on the Modified Mercalli scale. 

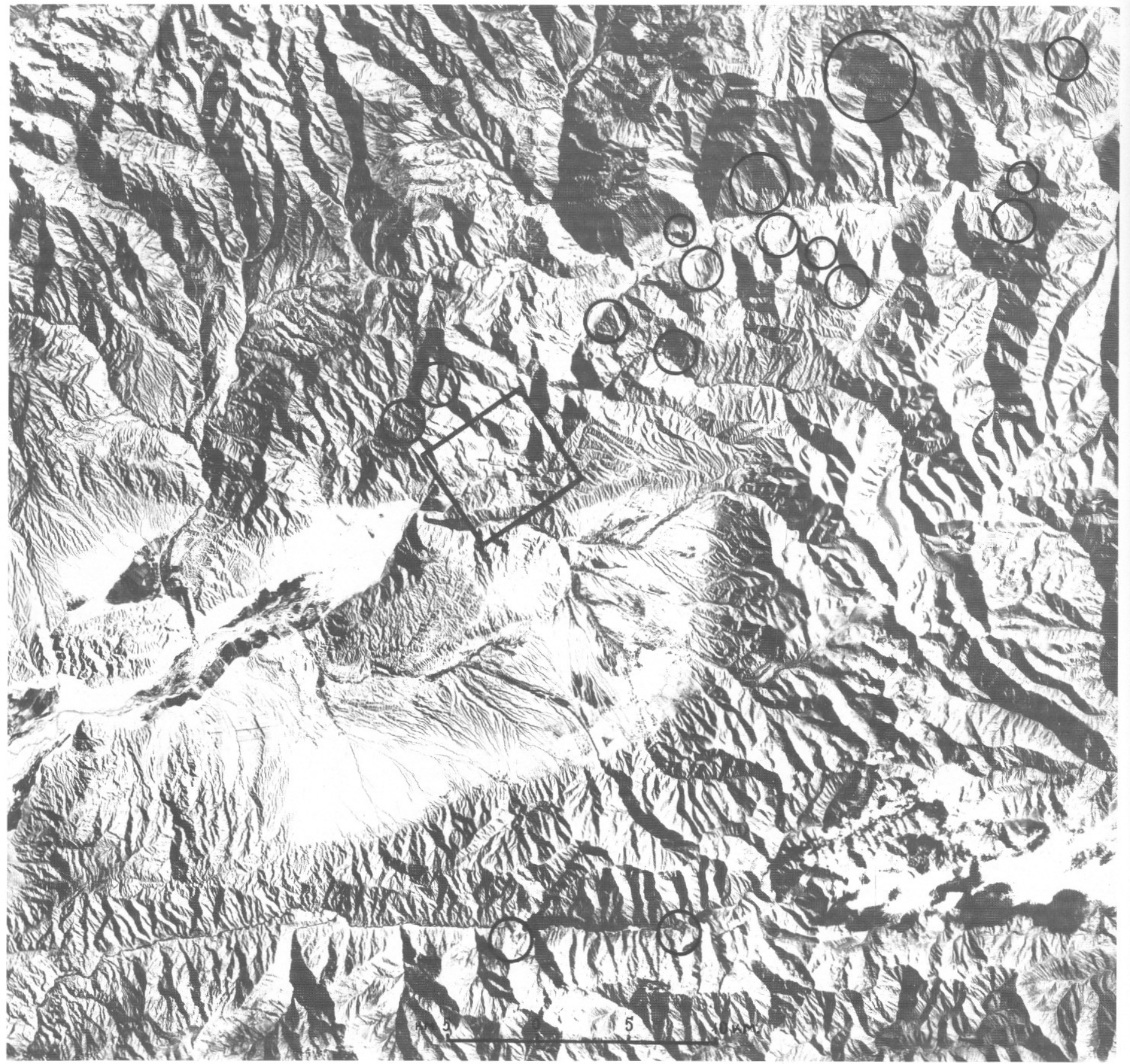

Figure 2.-Detailed space photograph of the central part of the area shown in figure 1. Circles mark some recent dislocations. The outlined area is figure 4.

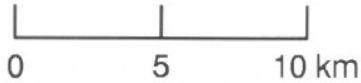

\section{Permafrost zone mapping}

The permafrost zone extends over vast areas of the USSR. This zone is characterized by unique geological conditions and engineering requirements. Trofimov (1989) defined the most important aspects of the permafrost as follows:

(1) Permafrost represents a specific class of deposit, in which the properties of the ground depend largely upon the amount of embedded ice. These properties are dependent upon temperature and undergo abrupt alterations relative to changes in temperatures.
(2) A wide variety of freezing processes are active in these areas. Cryogenic processes lead to the progressive development and formation of new permafrost and types of cryogenic relief, whereas the postcryogenic processes lead to the degradation of permafrost and the formation of typical landforms. Such landforms include thermokarst of varying size and morphology and hummocky ground.

(3) The presence of perennially frozen grou-d evokes a radical change in the hydrogeological structure of the region. As a consequence, the role of permafrost is a factor that controls the 


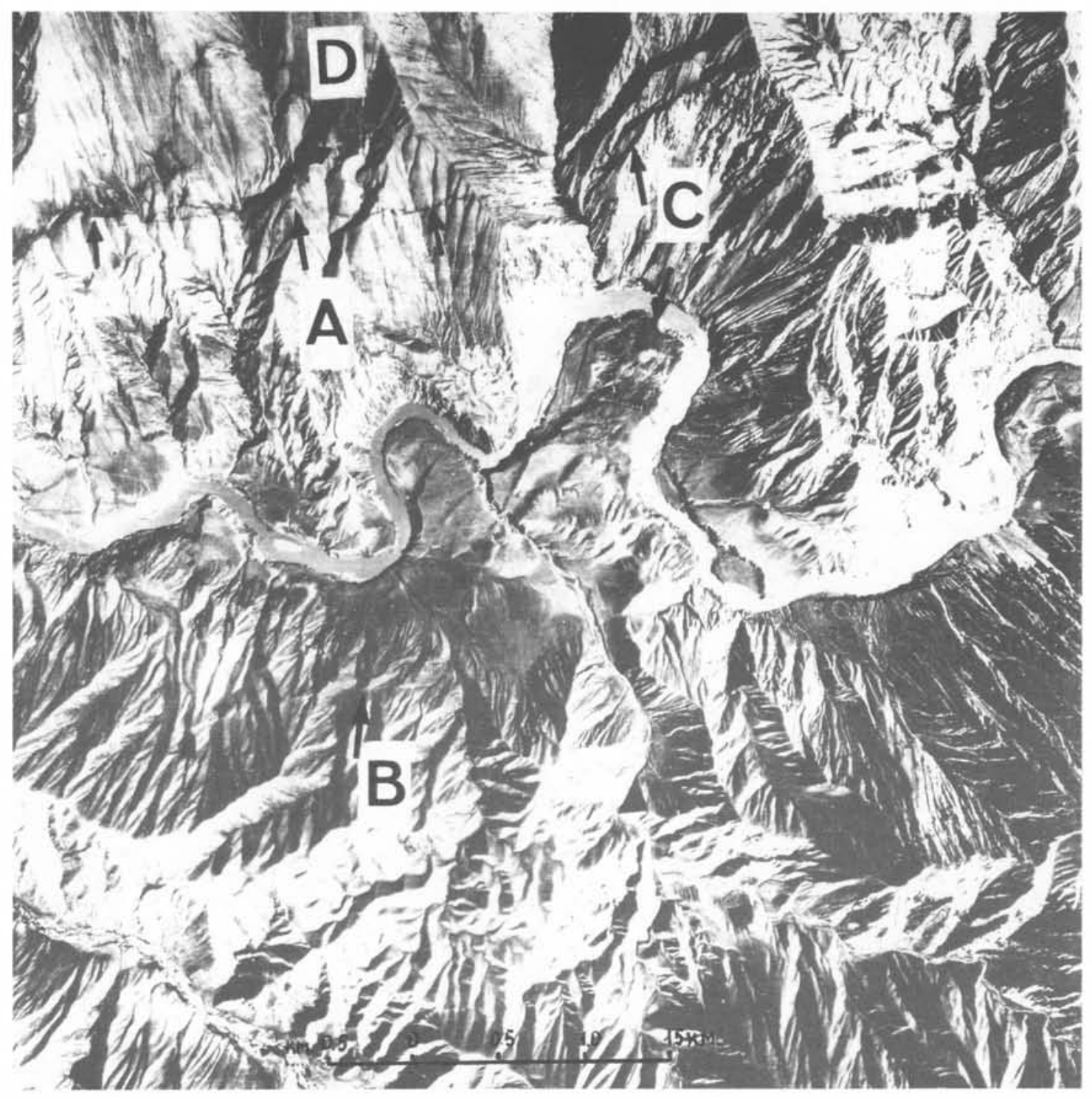

Figure 4.-Aerial photograph of the area marked in figure 2. Arrows show recent dislocations. $A$ and $B$ are faults, and $C$ and $D$ are rockfalls.

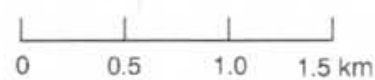

for the risk assessment of landslides, mudflows, rockfalls, erosion, and karst topography. Aerospace photographs help to assess the roles of climatic zones and structural and tectonic factors in the dynamics of these processes.

In order to map these hazard processes, techniques of comparative analysis of photographs taken at different times, chronomorphostructural analysis, principles of identifying images, and systems of electronic-optical transformation are used. The KuraminChatkal mountain area of central Asia, mapped at a scale of 1:200,000 (fig. 5), shows different lithological deposits, tectonic structures, and the development and evolution of landslides, mudflows, and mud avalanches.

\section{Environmental aspects}

The geological environment is undergoing continuous changes that are caused either by natural geological processes or by anthropogenic and technological processes. Different remote sensing methods are employed in order to study man's impact on the geological environment. For example, the engineering-geodynamics map of the Aral Sea, compiled at a scale of $1: 1,000,000$, shows changes in the area and provides a forecast for changes continuing to the year 2000 (fig. 6).

\section{Conclusions}

$\mathrm{T}_{\text {his paper has discussed briefly some examples of the use of remote }}$ sensing in engineering geology in the USSR. Remote sensing methods and techniques are used for many purposes such as hydrogeolo$\mathrm{gy}$, irrigation projects, mining, the development of urban and coastal areas, and linear construction. Furthermore, a remote sensing system is now under development for monitoring areas of intensive human impact. 


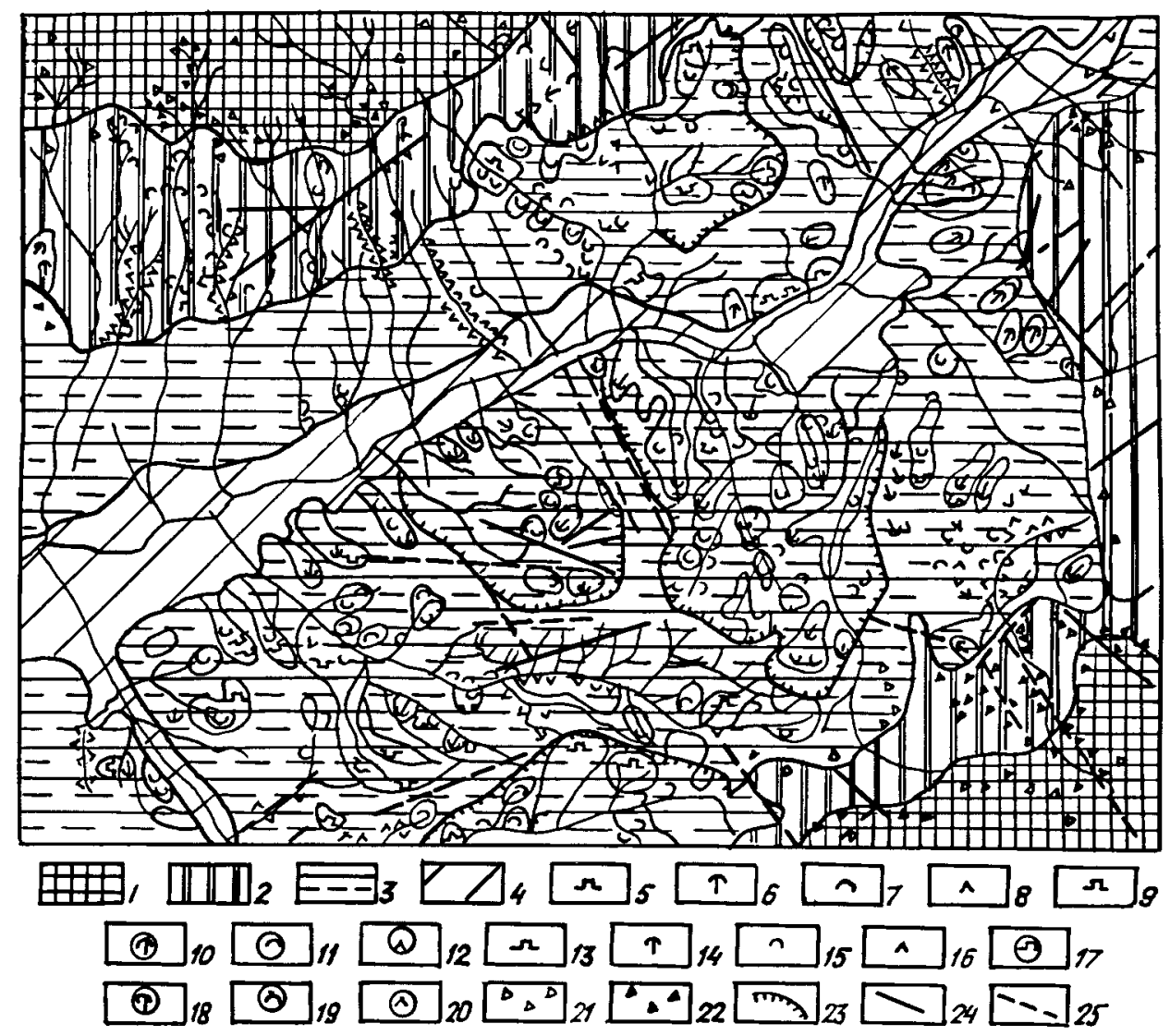

igure 5. - Kuramin-Chatkal mountainous territory of central Asia towing engineering geology classification areas mapped at a scale f 1:200,000. Explanation: 1, highlands showing erosionalnudational relief in hard rocks of the Paleozoic Era; 2, middleight lands and lowlands showing erosional-denudational relief on ard and semihard rocks mainly of the Paleozoic Era but with a thin over of loose sediments: 3 , piedmonts showing erosional relief on mihard and binder rocks of the Mesozoic and Cenozoic Eras and a iick cover of loessal soils; 4, piedmonts showing erosionalccumulative relief on semihard and binder rocks of the Cenozoic ra and a thin cover of loessal sediments. Fresh landslides: 5, locks; 6, flows; 7, mud streams; 8, mud avalanches. Areas of fresh andslides: 9, blocks; 10, flows; 11, mud streams; 12, mud avaanches. Old landslides: 13, blocks; 14 , flows; 15 , mud streams; 16 , nud avalanches. Areas of old landslides: 17, blocks; 18, flows; 19 , nud streams; 20, mud avalanches; 21 , fresh debris; 22, old debris; 3. ancient sliding cirques. Tectonic dislocations having a break in ontinuity: 24 , proven; 25 , inferred.

\section{References}

Ershov, E.D., Kondratieva, K.A., Zomolotchikova, C.A., Trush, N.I., and Gavrilov, A.B., 1984, Geocryological map of the USSR, scale 1:2,500,000: International Geological Congress, 27th, Moscow, 1984, Abstracts, v. 8, p. $39-40$.

Komarov, I.S., Akinfiev, C.A., Lyalko, V.I., Ogilivi, A.A., and Sheko, A.I., 1988, Methods of the study of geological processes in the regions of intensive technological impact: Problems of the geoenvironment: Moscow, Nauka Publishers, p. 61-84. [In Russian.]
Komarov, I.S., and Sadov, A.V., 1984, Aero-space methods in hydrogeological and engineering geological studies in the USSR: International Geological Congress, 27th, Moscow, 1984, Abstracts, v. 8, p. 71-72.

Radchenko, E.K., 1984. Methods of remote sensing of hydrogeological and engineering geological changes in the areas of drainage and irrigation: International Geological Congress, 27th, Moscow, 1984, Abstracts, v. 8 , p. $131-133$.

Sadov, A.V., and Revson, A.L., 1979, Aerospace methods in engineering geodynamics: Moscow, Nedra Publishers, 206 p. [In Russian.]

Trofimov, V.T., 1989, Engineering geology of the permafrost zone, in Dearman, W.R., Sergeev, E.M., and Shibakova, V.S., eds., Engineering geology of the Earth: Moscow, Nauka Publishers, p. 40-63. $\square$

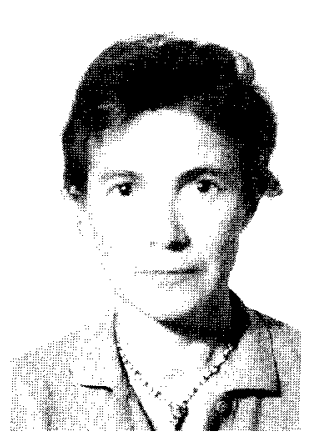

Dr. Valentina S. Shibakova is a Senior Scientist in the Geological Institute of the USSR Academy of Sciences, Pizevsky 7, 109917 Moscow, USSR. She is the Scientific Secretary of the Council on Engineering Geol. ogy and Hydrogeology of the USSR Academy of Sciences. Dr. Shibakova specializes in the study of soil and rock properties and in the develop. ment of the method of soil stabilization by the use of microwaves. She is a member of the International Association of Engineering Geology (IAEG) and recently served as coeditor of the IAEG publication entitled "Engineering Geology of the Earth." 


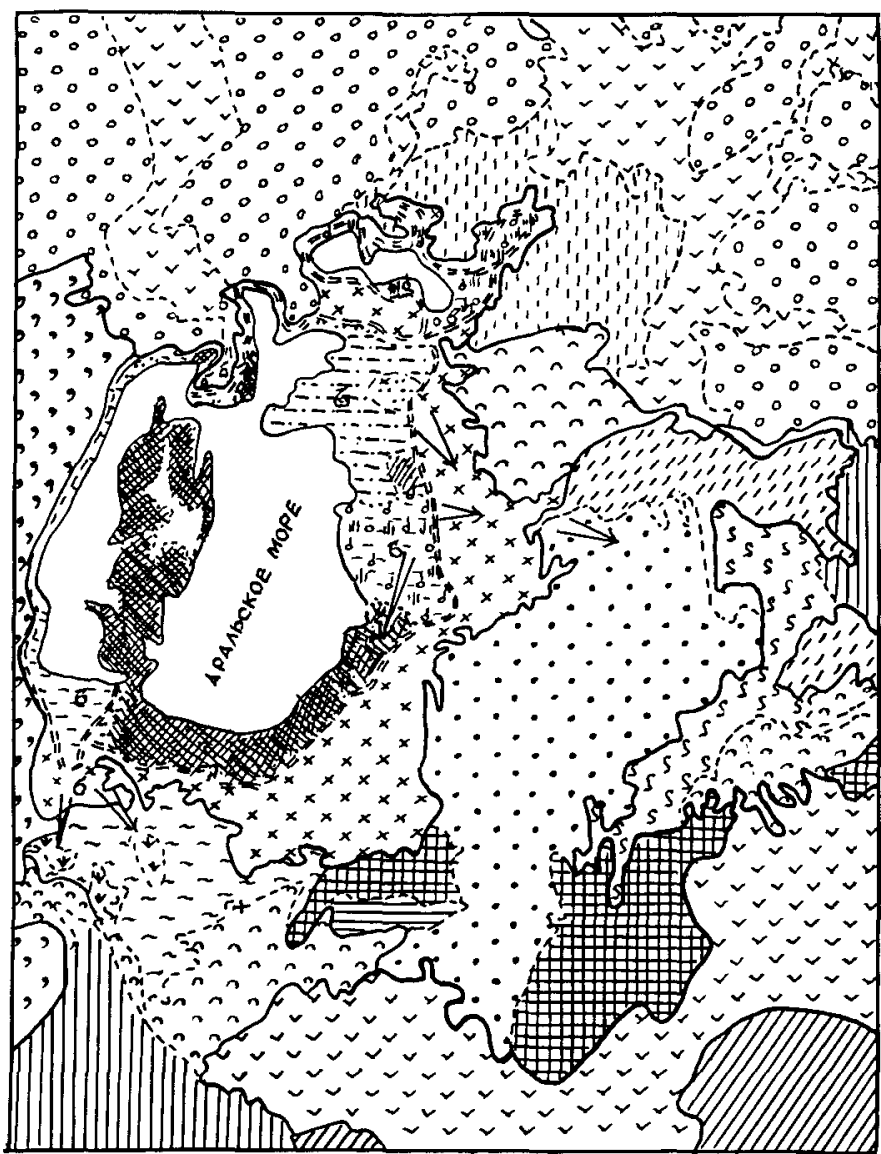

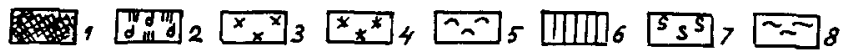

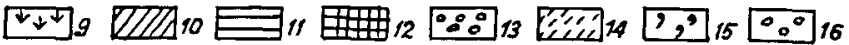

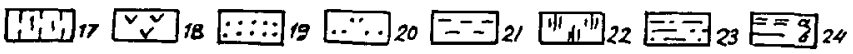
$\square_{25} \square_{26} \ldots_{27}\left[\begin{array}{l}28 \\ { }_{29}\end{array}\right.$

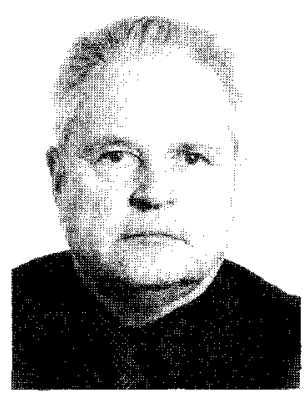

Dr. Aleksey V. Sadov is Professor and Chief of the Aerocosmic Research Methods Laboratory at the All-Union Research Institute for Hydrogeology and Engineering Geology (VSEGINGEO), 142452 Zeleniy-village, Noginsk district, Moscow region. He is an Expert-Supervisor for Remote Sensing at the USSR Ministry of Geology.

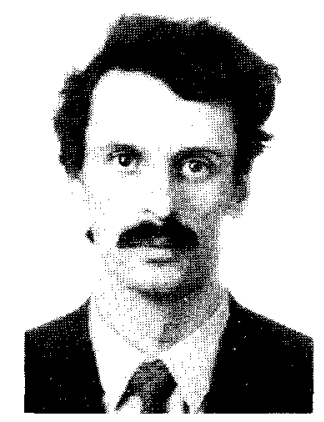

Dr. Aleksander L. Strom, a graduate of Moscow State University, is the Group Supervisor of the Geophysical Department of the Hydroproject Association, Volokolamskoje Shosse, 2, A-80, 125812 Moscow, USSR. He works in the fields of seismogeology and the applications of remote sensing methods for seismogeological investigations.
Figure 6.-Aral Sea region showing the classifications of the engineering geodynamicsm of a changing geological environment that is predicted will result from the impact of humankind.

Area 1 of the Aral Sea and adjacent zones changing as a result of the lowering of sea level. Explanation: 1 , sandy beaches undergoing deflation and subsequent redeposition of sand $\left(I_{1}\right) ; 2$, wet and swelling Solonchak soils on exposed marine clays and loams and subsequent deflation of swelling Solonchaks $\left(I_{2}\right) ; 3$, drving of wet Solonchaks, destruction of gypseous crusts, desalinization of rocks, and deflation of sands of the earlier exposed sea floor $\left(I_{3}\right) ; 4$, damping of sliding processes due to sea retreat $\left(I_{4}\right)$.

Area II of changing environment that has been influenced by land-reclamation measures. 5, Induced rise in phreatic water level from 5 to $10 \mathrm{~m}$ up to 1 to $5 \mathrm{~m}$ below the land surface and the resulting changes in chemical composition and mineral content, incidental salting of deposits and waste lands, and formation of tugai vegetation along irrigation canals $\left(I_{1}\right) ; 6$, stable hydro-reclamation regime of oasis lands $\left(I_{2}\right) ; 7$, improvement of pastures and growth of phreatophytes as a result of the rise in phreatic water level caused by discharge of irrigation water into old riverbeds and restoration of black-saxaul forests $\left(I_{3}\right) ; 8$, lowering of the phreatic water level from $0.5 \mathrm{~m}$ to $10 \mathrm{~m}$, partial desalinization of soils, death of tugai vegetation, and deflation of intradelta sands $\left(\mathrm{II}_{4}\right) ; 9$, formation of swelling Solonchaks on the areas of dried lakes and subsequent deflation of salts $\left(I_{5}\right)$.

Area III containing changes due to man-induced impacts that are not related to land-improvement measures. 10, Disturbances in soil and vegetation covers and formation of land dumps and ravine system as a result of mining works $\left(I I_{1}\right) ; 11$, moderate deflation due to pasturing and salt pulverization $\left(\mathrm{II}_{2}\right) ; 12$, extension of near-well lakes and Solonchaks, as well as tugai formation and secondary redistribution of sand resulting from intensive pasturing $\left(\mathrm{III}_{3}\right) ; 13$, extension of near-well and natural Solonchaks due to salt pulverization from the dried sea bottom and formation of secondary saltdeflation sites $\left(\mathrm{II}_{4}\right) ; 14$, secondary deflation of small sandy masses resulting from increased pasturing $\left(\mathrm{II}_{5}\right) ; 15$, surface destruction of high gypsum-content soils in Ustyurt plateau and subsequent deflation due to intensive traffic $\left(I I_{6}\right)$.

Area $I V$ showing moderate changes as a result of slight impacts induced by man. 16, Moderate evolution of ravine erosion, salting, and takyr formation $\left(I V_{1}\right) ; 17$, Solonchak degradation of takyrs, salting of sands, and increase in salt pulverization from the dried sea bottom $\left(I V_{2}\right) ; 18$, moderate deflation of sands $\left(I V_{3}\right)$. Lithological differences of exposed marine soils resulting in the prevalence of 19 , sand; 20, sands and sandy loam; 21, sandy loam, loam, and silt; 22, salted soils; 23, loam and sandy loam. Also shown are 24 a, Aral Sea level in 1986; 24b, predicted Aral Sea level for the year 2000; 25, areas of changes in the geological environment due to different man-induced activities; 26 , areas showing prevalence for particular changes in the geological environment; 27 , lithological differences in soils of the exposed sea bottom; 28, sites of the most active salt deflation; and 29, basic directions of salt movement. 